\title{
Omani Higher Education Students' Attitude Towards Work During Study
}

\author{
SAFA AL HABSI and ARABY MADBOULY* \\ Department of Business and Accounting, Muscat College, Sultanate of Oman.
}

\begin{abstract}
The work during study is widespread matter world wide and in the Sultanate of Oman as well. Many Omani students are noticed work during their study. The aim of this research is to analyze the attitude of higher education Omani students towards working during study via identifying benefits they obtain and challenges they face. The quantitative research methodology was implemented via survey approach using structured questionnaire technique. The questionnaire was prepared and distributed to 220 higher education students. 102 respondents have responded $(46.3 \%)$. The main findings of the research are: i) Majority of Omani higher education students work during study and the plurality of them are placed in private sector organizations; ii)The "trading" and "other services" sectors absorbs above $70 \%$ of students who work during study; iii) $86 \%$ of these students joined work in the same area of their study; iv) Enhancement of soft skills is the highest benefit they obtained while the social challenges are considered the highest challenge they face. The outcomes of this study might be helpful to the Ministry of Higher Education, Research and Innovation (MOHERI) as it highlightsthe importance of having training in the offered higher education programs. MOHERI can also can also recognize challenges face working students and take some actions to eliminate these challenges.
\end{abstract}

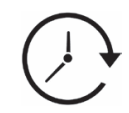

Article History

Received: 28 July 2021

Accepted: 31 August

2021

\section{Keywords}

Higher Education

Students;

Oman; Student's

Attitude;

Working During Study.

\section{Introduction}

Higher education is considered one of important determinant phases for the career of any student as it enriches him/ her with knowledge, skills and attributes which contribute in forming him/ heron both personal and professional levels (Creed et al. 2015). Many of students, even males or females, in this phase try to joina job during their study. Students take this step motivated by three categories of factors. i) social factors, like enable them to foster the networking and been familiar with the work conditions (Polidano et al. 2011); ii) financial factors, as having such work will participate in generate income which support in the payment of

CONTACT Araby Madbouly 1 araby@muscatcollege.edu.om Sultanate of Oman.

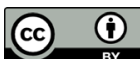

(C) 2021 The Author(s). Published by Enviro Research Publishers.

This is an 2 Open Access article licensed under a Creative Commons license: Attribution 4.0 International (CC-BY).

Doi: http://dx.doi.org/10.12944/JBSFM.03.01-02.11 
tuition fees and meet other costs (Sovereign et al., 2013) and iii) psychological factors, aswork during study enablesstudents to have self-recognition via developing ability to prove themselves and been more self-confident (Patterson, F 2004).

Although the literature reflected many benefits obtained by students who work during their study (Di Paolo et al 2016) and challenges face them, there are very few studies investigated this relationship for Omani students. Therefore, this study aims at identify the benefits and challenges of working during study for higher education Omani students. To achieve this aim, the research needs to answer the following questions: i) To what extent do Omani students prefer to work during their studies? ii) What are the benefits do work students get during their studies? iii) What are the challenges face students who work while studying? and iv) To what extent there is a difference between females and males in their attitude towards the work during their study?

This research consists of five sections, this introductory section is followed by the survey of related literature in the second section. The third section clarifies the research methodology where the analysis and results are provided in the fourth section. Finally, the fifth section includes the discussion and conclusion of the research.

\section{Literature Review}

\section{Benefits of Working While Studying}

A wide range of advantages can be obtained by students when join work during their study, whether the work is in full-time or part-time mode. Advantages are obtained also if students join online jobs (Hovdhaugen, E., 2015). The following sub sections highlight these benefits as found by the literature.

\section{Generate Income}

Joining work enables higher education students to generate income (Salamonson, Y., et al, 2020) which enable to meet the study requirements which include tuition and other related fees. Generated income will enable students to avoid stress resulted from the study and avoid debt (Hariri, H.B., 2001).

\section{Enhance the Soft Skills}

One of biggest challenges face higher education students is the lack of time management skills. Hence, having a job will foster their ability to manage their time and schedule the required tasks. Obtaining this skill will enable them to be improved in managing their study, properly schedule the group meetings with their colleagues, prioritize the tasks and submit their work on time. Feeling the responsibility toward the work and the study will foster this skill and enable the student to feel the value of the time (Al-Khawaja, M.Y.S, 2011).

Team working and communication skills are also considered advantages students positivity obtain during their study. The presence of colleagues in the organization will guide how to be effective team member, will improve their self-confidence and integration with others. It will also encourage to communicate effectively and with flexibility (Harvey, L., 2000). The communication covers written and verbal communication and listening, and this is related to brevity, focus and clarity as well as the ability to adapt his/ her message to others and listen to their opinions (Schill, W. J., Mc Cartin, R., \& Meyer, K.,1985).

Steinberg, et., al (1981) found that students who work during their studies have better decisionmaking skills compared to other counterparts. Furthermore, they can demonstrate priority setting and work with productivity, efficiency and excellent time management, and also by showing employers how to prioritize the given tasks decide what is important to accomplish and focus on it and how to deal with deadlines.

\section{Foster the Job Searching Skills}

Hovdhaugen (2015) Emphasized that university graduates need to search for suitable job, having a job during their study enables them to understand the required competencies and being aware with the career aspirations for the future and then search accordingly. Working enables students to have the experience search for a job closer to their career path (Almunif, A. M., 2008) and make them more familiar with the work requirements and the tendency of the labour market (Haapanen, M. and Karhunen, H., 2017). Having work experience during study provides also clarity about how to transform the business career(Ward, S., and Volet, S., 2008). Salamonson, et al., (2020) indicated that students can acquire valuable practical skills and experiences and ability to explore important opportunities for communication that can stimulate career graduation. 
Similar result found by Hall (2010) who evidenced that gaining work experience, even in areas not related to student's specialization is considered a very important benefit.

\section{Have More Networking Opportunities}

Montmarquette Viennot-Briot \& Dagenais (2007) highlighted that on the job, students will meet employees, HR specialists and managers while working in a nearby job. This will enable them to create professional contacts that can help them during their future careers.

\section{Improve Grades and Graduation Rates}

Sinaga (2018) evidenced that the work helps in improving academic performance. It was found that students who work during study can perform better because they become more able to function with bigger organizations. Dealing with professional people in the workand understanding the practical life requirements enable students to have more understanding about subject they study and realize the exact requirements which improve their academic performance.

On contrary of the aboveresults, some other literature found the work has a negative impact on academic performance. Callender, C. (2008). found term-time working has a negative impact on both final year marks and the degree results of students. The more hours students worked, the less marks they get. The same study also evidenced that students working average number of weekly hours are less likely to get a good degree compared to identical non-working peers. Similar result found for nursery students by Salamonson., et. al. (2012) who evidenced that negative association between hours spent in paid work during term-time and the results of nursing students. Similar result found by Catherine (2005) for undergraduate social work.

Kalenkoski and Pabiloniab (2012) found although the ability of academic performance interacts with the study time, the amount of time spent studying or at work has no direct impact on student's academic performance.

\section{Maturity and Sense of Responsibility}

Nonis\& Hudson (2006) Argued that responsibility is an element of maturity. The maturity, includes selfdiscipline and goal independence, is noticed as a characteristic for those who work during their study. They been responsible not only for themselves but for the organization which belong to. The sense of responsibility among students who inspires them to perform with independency and been able to focus on building their self-discipline.

\section{Challenges Facing Students who Work While Studying}

There are many challenges that hinder and face students while studying about educational attainment and also increase the pressures of daily life (Al-Qahtani, S.S., 1998).

\section{Difficulty in Time Management and the Balance between the Work and Study}

Lowe and Gayle (2007) found that although majority of the working students were able to balance between work, life and study, some experienced stress caused by conflicting priorities. Students who work and study spend about 8 to 12 hours in work which makes them very exhausted and face a challenge even to follow up their classes. Moreover, sometimes students feel the need to work in double shifts which is painful (Angelista, J. L., 2018). The work stress creates a difficulty in their ability to manage the time and balance between work and studies which has many consequences, even form the work side when they been slackening or not able to meet the work requirement properly (Dababneh and Awawdeh, 2012) or on the study side like the procrastination of the study duties. It also might lead to high absenteeism from classes and their names being dropped from class lists.

The stress from two sides and the difficulty in balance may lead to take a decision to postpone work or the study (Tymon, A., 2013) or drop the work (Fusco, D., 2012). Fakhro A. (2020)noted that it is necessary for working students to seek professional help to be able to organize their duties and deal with each task as needed.

\section{Social Challenges}

Jackson (2017) Noted that work is an important matter for students who cannot afford to pay their study. However, their social life is complicated, as they hardly give time to anyone else or been interested to something rather than study and work. This leads to less engagement with the family and 
almost no contact with friends (Gribble, C., Rahimi, M., \& Blackmore, J, 2017).

\section{Psychological Challenges}

Tomlinson (2007) observed that students who work during study might feel that family and friends impede the study or feel they are always busy with no freedom at all. They prefer to be isolated from family and reduction of time spend with them, especially during the weekends or gathering with friends. It is difficult for students who work during their study time to enjoy themselves, so it follows that their friends feel neglected. Moreover, Alsaudi (2016) found that students feel lonely when they go to work and hurry home so that they can study, and this in itself keeps them away from everyone and also sleep late, wake up early, be tired by the end of the week, and leave room for socialization because their schedule can become narrower. In the same vein, Kalenkoski and Pabiloniab (2012) found work during study decreases the time students spend on homework, which is human-capital building,

\section{The Theoretical Framework \\ Research Methodology}

Quantitative research method has been implemented to achieve the research aim and answer its' questions. Survey approach has been used to collect the data via questionnaire technique as it is considered the most common way to classify information (Harmouche, 2020). The questionnaire was distributed in online mode to ensure that it reaches quite large number of respondents and to save time (Mohammadlu, A. and Ramazanakhani, A., 2019). The assessment for each benefit and challenge in the questionnaire was measured on 5-point scale, ranging from 1 to 5 , as follows: 5 (strongly agree); 4(agree); 3 (neutral); 2 (disagree) and 1 (strongly disagree). Omani higher education students were the population. The link to the questionnaire was shared to them via emails and WhatsApp messages. The link was sent to 220 students and 102 responses have been received $(46.3 \%)$.

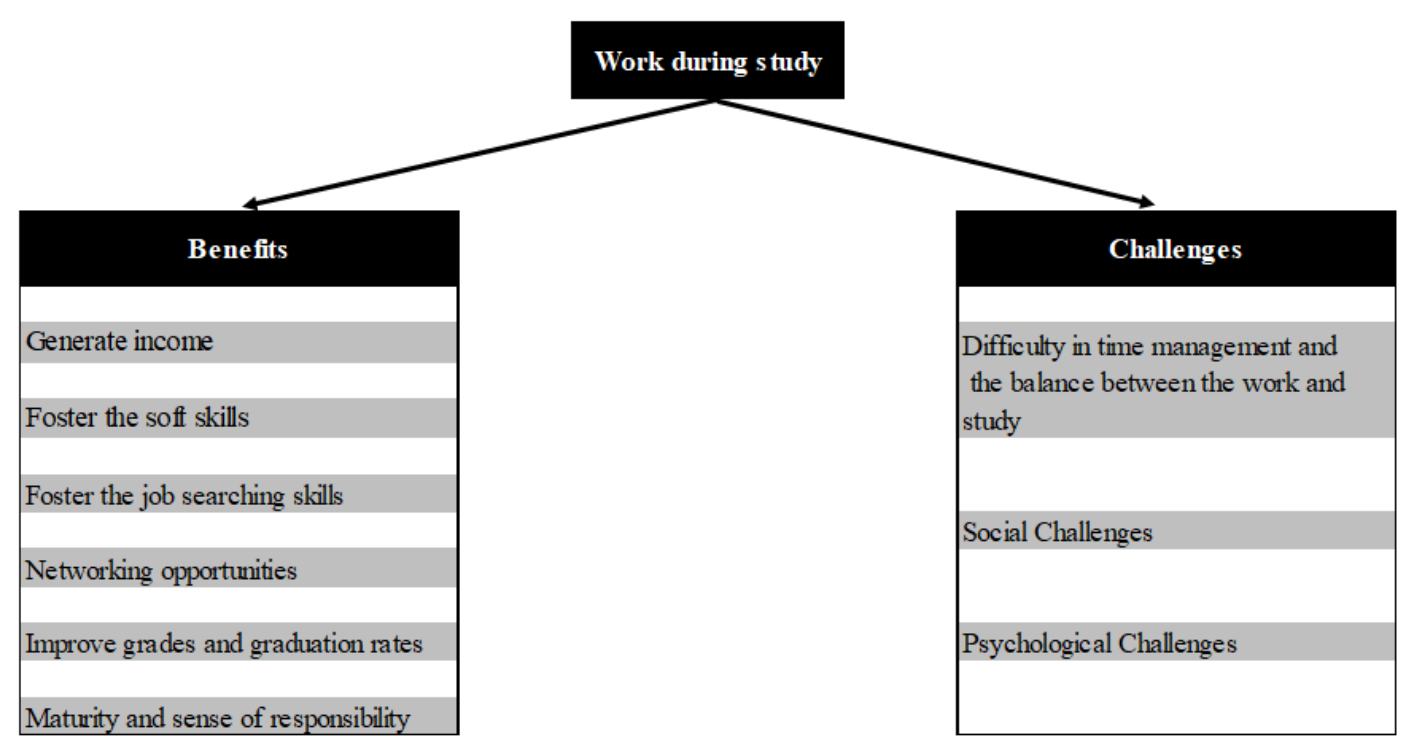

Fig.1: the theoretical framework of this study

Source: Developed by authors

The reliability test was conducted using Cronbach's alpha. The results are demonstrated in the following table. The value for the variables for Benefits is 0.914 and for challenge is 0.917 . These results reflect high level of internal consistency in the responses to both "benefits" and "challenges" and that it is sufficiently reliable to use the collected data in the analysis.
Reliability test

\begin{tabular}{lcc}
\hline & Cronbach's Alpha & N of Items \\
\hline Benefits & .914 & 12 \\
Challenges & .917 & 7 \\
\hline
\end{tabular}


Vol 03(1-2) 110-121 (2021)

The data has been analyzed using frequencies for the basic data, descriptive statistics to assess the benefits and challenges for students who work during their study. Finally, ANOVA test was used to determine if there is any difference between the male and female respondents towards these benefits and challenges.

Table 1: Gender Distribution

\begin{tabular}{lcccc}
\hline Gender & Frequency & Percent & Valid Percent & Cum. Percent \\
\hline Male & 33 & 32.4 & 32.4 & 32.4 \\
Female & 69 & 67.6 & 67.6 & 100.0 \\
Total & 102 & 100.0 & 100.0 & \\
\hline
\end{tabular}

Table 2: Institution of study

\begin{tabular}{lcccc}
\hline Institution of study & Frequency & Percent & Valid Percent & Cum. Percent \\
\hline Public HEI & 38 & 37.3 & 37.3 & 37.3 \\
Private Public HEI & 64 & 62.7 & 62.7 & 100.0 \\
Total & 102 & 100.0 & 100.0 & \\
\hline
\end{tabular}

Table 3: Are you working during you higher education study?

\begin{tabular}{lcccc}
\hline \multirow{2}{*}{ work during study } & Frequency & Percent & Valid Percent & Cum. Percent \\
\hline \multirow{2}{*}{ yes } & 79 & 77.5 & 77.5 & 77.5 \\
No & 23 & 22.5 & 22.5 & 100.0 \\
& 102 & 100.0 & 100.0 & \\
\hline
\end{tabular}

Table 4: Mode of employment

\begin{tabular}{lcccc}
\hline Mode of employment & Frequency & Percent & Valid Percent & Cum. Percent \\
\hline Full time & 57 & 72.2 & 72.2 & 72.2 \\
Part time & 22 & 27.8 & 27.8 & 100.0 \\
Total & 79 & 100.0 & 100.0 & \\
\hline
\end{tabular}

Table 5: Type of employer

\begin{tabular}{lcccc}
\hline Type of employer & Frequency & Percent & Valid Percent & Cum. Percent \\
\hline Public & 34 & 43.1 & 43.1 & 43.1 \\
Private & 45 & 56.9 & 56.9 & 100.0 \\
Total & 79 & 100.0 & 100.0 & \\
\hline
\end{tabular}


Vol 03(1-2) 110-121 (2021)

Table 6: Sector of the employer

\begin{tabular}{lcccc}
\hline Sector of the employer & Frequency & Percent & Valid Percent & Cum. Percent \\
\hline Trade & 29 & 36.7 & 36.7 & 36.7 \\
Manufacturing & 16 & 20.3 & 20.3 & 57.0 \\
Tourism & 6 & 7.6 & 7.6 & 64.6 \\
other services & 28 & 35.5 & 35.4 & 100.0 \\
Total & 79 & 100.0 & 100.0 & \\
\hline
\end{tabular}

Table 7: Is your work in the same area of your study?

\begin{tabular}{lcccc}
\hline $\begin{array}{l}\text { Matching between the areas } \\
\text { of the work and the study }\end{array}$ & Frequency & Percent & Valid Percent & Cum. Percent \\
\hline Yes & 68 & 86.1 & 86.1 & 86.1 \\
No & 11 & 13.9 & 13.9 & 100.0 \\
Total & 79 & 100.0 & 100.0 & \\
\hline
\end{tabular}

\section{Analysis}

Analysis of the General Data - Frequency Analysis

The data about respondents' gender, type of Institution of study, the status of work during study, the mode of employment, type and sector of employer and the matching between the areas of the work and the study have been demonstrated in table 2 to table 8 below.

Tables 1 to 7 demonstrates the frequencies of the basic data of respondents. It's found that majority of respondents (68\%) are females, $63 \%$ of respondents study in private Higher Education institutions (HEls). The data demonstrated in table 3 reflects that majority $(78 \%)$ of Omani higher education students are working during their study. $57 \%$ of them joined private sector organizations, while $43 \%$ joined public sector. $72 \%$ of them joined full time job. $37 \%$ of these students joined "Trading sector", $36 \%$ joined the "Other services" sector, $20 \%$ joined the "Manufacturing sector" and $8 \%$ got job in the "Tourism sector". $86 \%$ of these students joined work in the same area of their study.

Benefits and Challenges of Work During Study - Descriptive Analysis

The data presented in table 8 reflects the respondents' reflection about the benefits which students gain when they work during study. While the reflections about the challenges are presented in table 8.
Data demonstrated in table 8shows that respondents reflect high agreement about the benefits gained from work during study, as the overall score given to benefits is 3.84 out of 5.0 . The highest benefit students gain when they join work during study is the "Enhance the Communication skills" where the mean score is 4.2 , followed by the "Enhancement of the Decision-making skills" with score 3.9. The improvement of grades and graduation rates came in the third rank with score 3.89. The "Maturity and sense of responsibility" and the "Enhance the time management skills" are found the lowest benefit obtained with score 3.74 .

Overall, it can be seen from table (9) that respondents reflect medium challenges faced when students work during study, as the overall score is 2.47 out of 5.0 and all the given scores are less than 3.0. All challenges get scores between 2.2 and 2.6. The highest challenge face them is the "Less engagement with family and friends" with score 2.63 followed by "Social consequences, family problem that hinder study" with score 2.58. This reflects that the social challenges are considered the highest challenges face students when they join work during study. The "Difficulty to balance between the work and studies" found the lowest challenge with score 2.3. 
Vol 03(1-2) 110-121 (2021)

Table 8: Benefitsof work during study - Descriptive analysis

\begin{tabular}{lccccc}
\hline Item & N & Minimum & Maximum & Mean & Std. Dev. \\
\hline Generate income & $\mathbf{1 0 2}$ & $\mathbf{1 . 0}$ & $\mathbf{5 . 0}$ & $\mathbf{3 . 8 4 3}$ & $\mathbf{1 . 3 0 3 0}$ \\
Enhance the soft skills & & & & $\mathbf{3 . 9 0 5}$ & \\
Enhance the time management skills & 102 & 1.0 & 5.0 & 3.735 & 1.2342 \\
Enhance the Communication skills & 102 & 1.0 & 5.0 & 4.166 & 1.0538 \\
Enhance the teamwork skills & 102 & 1.0 & 5.0 & 3.843 & 1.1322 \\
Enhance the Critical thinking skills & 102 & 1.0 & 5.0 & 3.852 & 1.1466 \\
Enhance the Decision-making skills & 102 & 1.0 & 5.0 & 3.931 & 1.1367 \\
Foster the job searching skills & $\mathbf{1 0 2}$ & & & $\mathbf{3 . 7 6 7}$ & \\
Foster the experience of search for a job closer & 102 & 1.0 & 5.0 & 3.774 & 1.0708 \\
to the career path & & & & & \\
More understanding to the labour market requirements & 102 & 1.0 & 5.0 & 3.784 & 1.1826 \\
clarity about the transform to the business career & 102 & 1.0 & 5.0 & 3.745 & 1.2161 \\
Have more networking opportunities & $\mathbf{1 0 2}$ & $\mathbf{1 . 0}$ & $\mathbf{5 . 0}$ & $\mathbf{3 . 7 5 4}$ & $\mathbf{1 . 2 3 0 2}$ \\
Improve grades and graduation rates & $\mathbf{1 0 2}$ & $\mathbf{1 . 0}$ & $\mathbf{5 . 0}$ & $\mathbf{3 . 8 9 2}$ & $\mathbf{1 . 1 1 6 1}$ \\
Maturity and sense of responsibility & $\mathbf{1 0 2}$ & $\mathbf{1 . 0}$ & $\mathbf{5 . 0}$ & $\mathbf{3 . 7 3 5}$ & $\mathbf{1 . 2 8 1 5}$ \\
Overall Score & & & & $\mathbf{3 . 8 3 7}$ & \\
\hline
\end{tabular}

Table 9: Challenges of work during study - Descriptive analysis

\begin{tabular}{|c|c|c|c|c|c|}
\hline Item & $\mathbf{N}$ & Minimum & Maximum & Mean & Std. Dev. \\
\hline Difficulty to balance between the work and studies & 102 & 1.0 & 5.0 & 2.2647 & 1.39962 \\
\hline Procrastination of the study duties & 102 & 1.0 & 5.0 & 2.5392 & 1.26391 \\
\hline Social Challenges & & & & 2.60295 & \\
\hline Less engagement with family and friends & 102 & 1.0 & 5.0 & 2.6275 & 1.30438 \\
\hline $\begin{array}{l}\text { Social consequences, family problem that } \\
\text { hinder study }\end{array}$ & 102 & 1.0 & 5.0 & 2.5784 & 1.30069 \\
\hline Psychological Challenges & & & & 2.39215 & \\
\hline Feeling lonely & 102 & 1.0 & & & \\
\hline 5.0 & 2.4118 & 1.18867 & & & \\
\hline Feeling isolated & 102 & 1.0 & & & \\
\hline 5.0 & 2.3725 & 1.31195 & & & \\
\hline Overall Score & & & & 2.466 & \\
\hline
\end{tabular}

\section{Anova Test For Gender's Differences Towards Work During Study}

Tables 10 and 11 demonstrates the outcomes of ANOVA test for the difference between genders towards benefits and challenges of work during study.

The above table shows that there is a difference between males and females' reflections towards four benefits gained by the work during study, they are "Gain better teamwork skills", "Gain better Critical thinking skills", "More understanding to the labour market requirements" and "Have more networking opportunities" while there is no significant difference between genders towards other benefits.

The above table shows that there is a significant difference between genders towards challenges face students who work during study in one challenge only "Feeling isolated" where no significant differences found in towards the other challenges. 
Vol 03(1-2) 110-121 (2021)

Table 10: The difference between genders towards benefits of work during study - ANOVA test

\begin{tabular}{|c|c|c|c|c|c|c|}
\hline & & Sum of Squares & df & Mean Square & $\mathbf{F}$ & Sig. \\
\hline Generate income & $\begin{array}{c}\text { Between Groups } \\
\text { Within Groups } \\
\text { Total }\end{array}$ & $\begin{array}{c}2.995 \\
168.495 \\
171.490\end{array}$ & $\begin{array}{c}1 \\
100 \\
101\end{array}$ & $\begin{array}{l}2.995 \\
1.685\end{array}$ & 1.777 & .186 \\
\hline $\begin{array}{l}\text { Enhance the time } \\
\text { management skills }\end{array}$ & $\begin{array}{c}\text { Between Groups } \\
\text { Within Groups } \\
\text { Total }\end{array}$ & $\begin{array}{c}.335 \\
153.518 \\
153.853\end{array}$ & $\begin{array}{c}1 \\
100 \\
101\end{array}$ & $\begin{array}{l}.335 \\
1.535\end{array}$ & .218 & .641 \\
\hline $\begin{array}{l}\text { Gain better } \\
\text { Communication skills }\end{array}$ & $\begin{array}{c}\text { Between Groups } \\
\text { Within Groups } \\
\text { Total }\end{array}$ & $\begin{array}{c}.011 \\
112.155 \\
112.167\end{array}$ & $\begin{array}{c}1 \\
100 \\
101\end{array}$ & $\begin{array}{l}.011 \\
1.122\end{array}$ & .010 & .921 \\
\hline $\begin{array}{l}\text { Gain better } \\
\text { teamwork skills }\end{array}$ & $\begin{array}{c}\text { Between Groups } \\
\text { Within Groups } \\
\text { Total }\end{array}$ & $\begin{array}{c}.781 \\
128.709 \\
129.490\end{array}$ & $\begin{array}{c}1 \\
100 \\
101\end{array}$ & $\begin{array}{c}.781 \\
1.287\end{array}$ & .607 & .438 \\
\hline $\begin{array}{l}\text { Gain better Critical } \\
\text { thinking skills }\end{array}$ & $\begin{array}{c}\text { Between Groups } \\
\text { Within Groups } \\
\text { Total }\end{array}$ & $\begin{array}{c}1.055 \\
131.739 \\
132.794\end{array}$ & $\begin{array}{c}1 \\
100 \\
101\end{array}$ & $\begin{array}{l}1.055 \\
1.317\end{array}$ & .801 & .373 \\
\hline $\begin{array}{l}\text { Gain better Decision- } \\
\text { making skills }\end{array}$ & $\begin{array}{c}\text { Between Groups } \\
\text { Within Groups } \\
\text { Total }\end{array}$ & $\begin{array}{c}.024 \\
130.495 \\
130.520\end{array}$ & $\begin{array}{c}1 \\
100 \\
101\end{array}$ & $\begin{array}{c}.024 \\
1.305\end{array}$ & .019 & .892 \\
\hline $\begin{array}{l}\text { Foster the experience of } \\
\text { search for a job closer to } \\
\text { the career path }\end{array}$ & $\begin{array}{c}\text { Between Groups } \\
\text { Within Groups } \\
\text { Total }\end{array}$ & $\begin{array}{c}.267 \\
115.547 \\
115.814\end{array}$ & $\begin{array}{c}1 \\
100 \\
101\end{array}$ & $\begin{array}{l}.267 \\
1.155\end{array}$ & .231 & .632 \\
\hline $\begin{array}{l}\text { More understanding to } \\
\text { the labour market } \\
\text { requirements }\end{array}$ & $\begin{array}{c}\text { Within Groups } \\
\text { Between Groups } \\
\text { Total }\end{array}$ & $\begin{array}{c}1.173 \\
140.082 \\
141.255\end{array}$ & $\begin{array}{c}1 \\
100 \\
101\end{array}$ & $\begin{array}{l}1.173 \\
1.401\end{array}$ & .838 & .362 \\
\hline $\begin{array}{l}\text { clarity about the } \\
\text { transform to the } \\
\text { business career }\end{array}$ & $\begin{array}{c}\text { Between Groups } \\
\text { Within Groups } \\
\text { Total }\end{array}$ & $\begin{array}{c}.089 \\
149.283 \\
149.373\end{array}$ & $\begin{array}{c}1 \\
100 \\
101\end{array}$ & $\begin{array}{l}.089 \\
1.493\end{array}$ & .060 & .807 \\
\hline $\begin{array}{l}\text { Have more networking } \\
\text { opportunities }\end{array}$ & $\begin{array}{c}\text { Between Groups } \\
\text { Within Groups } \\
\text { Total }\end{array}$ & $\begin{array}{c}2.251 \\
150.622 \\
152.873\end{array}$ & $\begin{array}{c}1 \\
100 \\
101\end{array}$ & $\begin{array}{l}2.251 \\
1.506\end{array}$ & 1.494 & .224 \\
\hline $\begin{array}{l}\text { Improve grades and } \\
\text { graduation rates }\end{array}$ & $\begin{array}{c}\text { Between Groups } \\
\text { Within Groups } \\
\text { Total }\end{array}$ & $\begin{array}{c}.014 \\
125.800 \\
125.814\end{array}$ & $\begin{array}{c}1 \\
100 \\
101\end{array}$ & $\begin{array}{l}.014 \\
1.258\end{array}$ & .011 & .916 \\
\hline $\begin{array}{l}\text { Maturity and sense of } \\
\text { responsibility }\end{array}$ & $\begin{array}{c}\text { Between Groups } \\
\text { Within Groups } \\
\text { Total }\end{array}$ & $\begin{array}{c}.477 \\
165.375 \\
165.853\end{array}$ & $\begin{array}{c}1 \\
100 \\
101\end{array}$ & $\begin{array}{l}.477 \\
1.654\end{array}$ & .289 & .592 \\
\hline
\end{tabular}

Table 11: The difference between genders towards challenges of work during study - ANOVA test

\begin{tabular}{|c|c|c|c|c|c|c|}
\hline & & Sum of Squares & df & Mean Square & $\mathbf{F}$ & Sig. \\
\hline \multirow{3}{*}{$\begin{array}{l}\text { Difficulty to balance } \\
\text { between the work and } \\
\text { studies }\end{array}$} & Between Groups & .135 & 1 & .135 & .068 & .794 \\
\hline & Within Groups & 197.718 & 100 & 1.977 & & \\
\hline & Total & 197.853 & 101 & & & \\
\hline \multirow{3}{*}{$\begin{array}{l}\text { Procrastination of the } \\
\text { study duties }\end{array}$} & Between Groups & .645 & 1 & .645 & .401 & .528 \\
\hline & Within Groups & 160.698 & 100 & 1.607 & & \\
\hline & Total & 161.343 & 101 & & & \\
\hline
\end{tabular}



Vol 03(1-2) 110-121 (2021)

\begin{tabular}{|c|c|c|c|c|c|c|}
\hline $\begin{array}{l}\text { Less engagement with } \\
\text { family and friends }\end{array}$ & $\begin{array}{c}\text { Between Groups } \\
\text { Within Groups } \\
\text { Total }\end{array}$ & $\begin{array}{c}.022 \\
171.821 \\
171.843\end{array}$ & $\begin{array}{c}1 \\
100 \\
101\end{array}$ & $\begin{array}{c}.022 \\
1.718\end{array}$ & .013 & .909 \\
\hline $\begin{array}{l}\text { Social consequences, } \\
\text { family problem that hinder } \\
\text { study }\end{array}$ & $\begin{array}{c}\text { Between Groups } \\
\text { Within Groups } \\
\text { Total }\end{array}$ & $\begin{array}{c}.749 \\
170.124 \\
170.873\end{array}$ & $\begin{array}{c}1 \\
100 \\
101\end{array}$ & $\begin{array}{c}.749 \\
1.701\end{array}$ & .440 & .509 \\
\hline Feeling lonely & $\begin{array}{c}\text { Between Groups } \\
\text { Within Groups } \\
\text { Total }\end{array}$ & $\begin{array}{c}.089 \\
142.617 \\
142.706\end{array}$ & $\begin{array}{c}1 \\
100 \\
101\end{array}$ & $\begin{array}{c}.089 \\
1.426\end{array}$ & .063 & .803 \\
\hline Feeling isolated & $\begin{array}{c}\text { Between Groups } \\
\text { Within Groups } \\
\text { Total }\end{array}$ & $\begin{array}{c}5.714 \\
168.129 \\
173.843\end{array}$ & $\begin{array}{c}1 \\
100 \\
101\end{array}$ & $\begin{array}{l}5.714 \\
1.681\end{array}$ & 3.399 & .068 \\
\hline
\end{tabular}

\section{Discussion and Conclusion}

The aim of this research is to identify the benefits and challenges of working during study for higher education Omani students. To achieve this aim, the research needs to answer the following questions: i) To what extent do Omani students prefer to work during their studies? ii) What are the benefits do work students get during their studies? iii) What are the challenges face students who work while studying? and iv) To what extent there is a difference between females and males in their attitude towards the work during their study? Quantitative research method has been implemented via questionnaire techniques. Findings of the data analysis are presented in section four above.

It's found that majority of respondents $(68 \%)$ are females and $63 \%$ of them study in private Higher Education institutions (HEls). This is complied with the student profile of higher education students in Oman as majority of them are females and also the number of students enrolled in private HEls are more than the number enrolled in the public HEls.

With regard to the student attitude towards work during study, it is found that majority $(78 \%)$ of Omani higher education students are working during their study. This might reflect the good motivation they have to work during study, as there are three categories of factors here: social (Polidano et al. 2011), financial (Sovereign et al., 2013) and psychological factors motivate to step on that matter (Patterson, F 2004). The majority of these students joined private sector organizations, this might result from the more flexibility in this sector rather than the public sector. Although these students found job opportunities in different sectors, companies work in "trading" and "other services" sectors absorbs above $70 \%$ of them. Two reasons may be behind this result, first is that majority of companies operate in Oman work in the field of trading or other services while a smaller number of factories are there. The second could be that manufacturing might require more stable employees which let them avoid recruit students and prefer to recruit graduates as they need much training to be familiar with such types of organizations rather than organizations work in the other sectors. One of most interesting finding here is that $86 \%$ of these students joined work in the same area of their study. This reflects the high level of consciousness with the importance of work in the same area of study and they prefer to start their career early rather than waiting till been graduated. Hence, they are willing to have the understanding of the practical life's requirements (Sinaga, 2018), get the experience in their career and obtain all the other work life benefits during their study to be fully ready and meet the market requirements once they been graduated.

With regard to the benefits do work students get during their studies, overall students reflected high level advantages they receive when join a job during their study. The overall score given to benefits is 3.84 out of 5.0 . The enhancement of soft skills is considered the highest benefit students obtained when they join work during study. The skills of "communication", followed by "decision making" and "critical thinking" are the highest gained skills. This might reflect the gap between the competencies which students obtain and the employer requirements. This might come in the same line with other literature were employers reflected that the highest gap between the work requirements 
and the graduate's competence is in the "decision making" and the "problem solving" which is closely related to the "critical thinking skills" (Al-Shehab, N., 2021).

The positive impact of the work on the student academic performance is a very valid advantage students obtained. This result came in line with (Sinaga, 2018) who evidenced that students can do better in their academic performance when they deal with professional people and been able to understand the life requirements. "Generating income" is another high advantage given to students who join work, as the work enable them to afford their tuition fees and other fees related to their study (Salamonson, 2020).

Overall, students who work during study face challenges in the "medium level", as the overall score is 2.47 out of 5.0 and all the given scores are less than 3.0. All challenges get scores between 2.2 and 2.6. Social challenges: "Less engagement with family and friends" and "Social consequences, family problem that hinder study" are considered the highest challenge face them. The stress students face from both work and study push them to be isolated and less engaged with the family and almost no contact with friends. In this position, students need to have a break from time to time and connect with family and friends during this breaking time (Gribble, 2017).

The outcomes of ANOVA test reflected no much significant differences between male and females towards the benefits or challenges found when they work during study. The differences were found in only four benefits (out of twelve) and one challenge (out of six). This reflects that there is agreement between male and female students about the majority of benefits and challenges they face when work during study.

The results of this study are highlighting the advantages and drawbacks of work while studying and its impact on Omani students might be helpful to the Ministry of Higher Education, Research and
Innovation about the importance of having training as compulsory module in all offered courses. This training might enable the student to get majority of benefits of work during study. This will significantly help in the employability of graduates. On another hand, HEls need to support students to overcome challenges they face when they join work during study. For example, the social challenges and the difficulty to balance between work and study, which could be eliminated via providing them training and conduct workshops to foster their ability to deal with such challenges.

The main limitation faced researchers was the less responsibility of respondents. However, the received number of responses was realistic which enabled researchers to conduct the analysis properly.

This research investigated the experience of higher education students towards the work during study. The outcomes of this research highlighted many areas of research that could be carried out in the future. The first recommended area of research could be overcoming the challenges students face during their studies. This study investigated the work during higher education study from the students' perspective as the questionnaire was designed to collect the feedback of students only. In this regard, it's suggested to investigate the same topic from the perspective of employers. This will enable to have a complete picture about this phenomenon and will enable to have proper recommendations to support students who work during their higher education studies.

\section{Acknowledgment}

I would like to thank the co-author for his significant contribution to the research.

\section{Funding}

The author(s) received no financial support for the research, authorship, and/or publication of this article.

\section{Conflict of Interest}

The authors do not have any conflict of interest. 


\section{References}

1. Alkhawaja, M.Y.S. (2011), "Mashrow' eBahthEtj ahatAlshbabNahwaThaqafatAl'amalAlhur:Dera sahMaydaniah fi MuhafazatAlgharbia", Journal of the Faculty of Arts,24 (1),1-106.

2. Al-Shehab, N., AL-Hashimi, M., Madbouly, A., Reyad, S. and Hamdan, A. (2021), "Do employability skills for business graduates meet the employers' expectations? The case of retail Islamic banks of Bahrain", Higher Education, Skills and Work-Based Learning, 11 (2), 349-366. https://doi.org/10.1108/ HESWBL-09-2019-0117

3. Angelista, J. L. (2018). "Challenges facing secondary school teachers in implementing career guidance and its implication on students future job choices". International journal of education and research, 6 (7), 101-110.

4. Atroszko, P. A., Andreassen, C. S., Griffiths, M. D., \&Pallesen, S. (2016). "The relationship between study addiction and work addiction: A cross-cultural longitudinal study". Journal of Behavioral Addictions, 5(4), 708-714.

5. Callender, C. (2008). "The impact of term-time employment on higher education students' academic attainment and achievement", Journal of Education Policy, 23:4, 359-377, https://doi. org/10.1080/02680930801924490

6. Catherine A. Hawkins, Michael L. Smith, Raymond C. Hawkins, II \& Darlene Grant. (2005). "The relationships among hours employed, perceived work interference, and grades as reported by undergraduate social work students", Journal of Social Work Education, 41 (1), 13-27,https://doi.org/ 10.5175/JSWE.2005.200202122

7. Creed, P. A., French, J., \& Hood, M. (2015). "Working while studying at university: The relationship between work benefits and demands and engagement and well-being". Journal of Vocational Behavior, 86, 48-57.

8. Dababneh, A.B.andA wdeh, A.A.(2012)."The reality of gender integration in the private sector- an analytical study of the transport group of companies", Jordanian Journal of Social Sciences, 15 (1), 1-2.

9. Di Paolo, A., \& Matano, A. (2016). The Impact of Working while Studying on the Academic and Labour Market Performance of Graduates: the Joint Role of Work Intensity and Job-Field Match. Working Paper in Progress, available at: https://www. aiel. it/cms/cms-files/submission/ all20160608164320.

10. Fakhrou, A. A. (2020). "The Problems Facing Students of College of Education at Qatar University A Path to Academic Accreditation".

11. Fusco, D. (Ed.). (2012). "Advancing Youth Work: Current Trends, Critical Questions, Routledge". New York, NY and London.

12. Gribble, C., Rahimi, M., \& Blackmore, J. (2017). "International students and post-study employment: The impact of university and host community engagement on the employment outcomes of international students in Australia". International Student Connectedness and Identity. Springer, Singapore, 15-39.

13. Haapanen, M., \&Karhunen, H. (2017). "Working while studying: does it lead to greater attachment to the regional labour market?". Graduate Migration and Regional Development. Edward Elgar Publishing.'

14. Hall, R. (2010). "The work-study relationship: experiences of full-time university students undertaking part-time employment", Journal of Education and Work, 23(5), 439-449,https://doi. org/10.1080/13639080.2010.515969

15. Harmouche-Karaki, M., Mahfouz, M., Obeyd, J., Salameh, P., Mahfouz, Y., \&Helou, K. (2020). "Development and validation of a quantitative food frequency questionnaire to assess dietary intake among Lebanese adults". Nutrition journal, 19(1), 1-19.

16. Harvey, L. (2000). "New realities: The relationship between higher education and employment". Tertiary Education \& Management, 6(1), 3-17.

17. Hovdhaugen, E. (2015). "Working while studying: The impact of term-time employment on dropout rates". Journal of Education and Work, 28(6), 631-651.

18. Jackson, D. (2017). "Exploring the challenges experienced by international students during work-integrated learning in Australia. Asia Pacific Journal of Education, 37(3), 344-359.

19. Kalenkoski, C. M. and Pabiloniab, S. W. (2012). "Time to work or time to play: The effect of student employment on homework, sleep, and screen time". Labour Economics, 19 (2), 

Vol 03(1-2) 110-121 (2021)

211-221

20. Lowe, J. and Gayle, V. (2007). "Exploring the work/life/study balance: theexperience of higher education students in a Scottish further education college", Journal of Furtherand Higher Education, 31(3), 225-238, https://doi. org/10.1080/03098770701424942

21. Mohamadloo, A., \&Ramezankhani, A. (2019). "Psychometric Design of a Questionnaire for the Prevention of Induced Demand for Medicine Prescription". Journal of Human, Environment and Health Promotion, 5(3), 104-109.

22. Montmarquette, C., Viennot-Briot, N., \&Dagenais, M. (2007). "Dropout, school performance, and working while in school". The Review of Economics and Statistics, 89(4), 752-760.

23. Nonis, S. A., \& Hudson, G. I. (2006). "Academic performance of college students: Influence of time spent studying and working". Journal of Education for Business, 81(3), 151-159.

24. Patterson, F. M. (2004). "Motivating students to work with elders: A strengths, social construction, and human rights and social justice approach". Journal of Teaching in Social Work, 24(3-4), 165-181.

25. Polidano, C., \& Zakirova, R. (2011). "Outcomes from Combining Work and Tertiary Study. A National Vocational Education and Training Research and Evaluation Program Report". National Centre for Vocational Education Research Ltd. PO Box 8288, Stational Arcade, Adelaide, SA 5000, Australia.'

26. Salamonson, Y., Roach, D., et., al. (2020). "The type and amount of paid work while studying influence academic performance of first year nursing students: An inception cohort study". Nurse education today, 84, 104-213.
27. Salamonson, Y., Roach, D., et., al. (2012). "The impact of term-time paid work on academic performance in nursing students: A longitudinal study". International Journal of Nursing Studies, 49 (5), 579-585

28. Schill, W. J., McCartin, R., \& Meyer, K. (1985). "Youth Employment: Its relationship to academic and family variables". Journal of Vocational Behavior, 26(2), 155-163.

29. Sinaga, H. D. (2018). "Influence of Studying While Working and Learning Motivation to Academic Achievement of College Students Majoring Information System at Stmik Royal Kisaran". Journal of Physics: Conference Series. 114 (1).

30. Sovereign House Church Institute for Employment Studies. National Centre for Social. (2013). Working while studying: a followup to the Student Income and Expenditure Survey 2011/2012.]

31. Steinberg, L. D., Greenberger, E., Vaux, A., \& Ruggiero, M. (1981). "Early Work Experience: Effects on Adolescent Occupational Socialization". Youth and Society, 12(4), 403422.

32. Tomlinson, M. (2007). "Graduate employability and student attitudes and orientations to the labour market". Journal of Education and Work, 20(4), 285-304.

33. Tymon, A. (2013). "The student perspective on employability". Studies in Higher Education, 38(6), 841-856.

34. Ward, S. and Volet, S. (2008). Working while studying: Impact on marketing students' experience of group work. In: ANZMAC 2008: Marketing: Shifting the Focus from Mainstream to Offbeat, 1 - 3 December 2008, Olympic Park, Sydney. 